\title{
Oilwells in Great Britain.
}

T $\mathrm{T}$ will be recalled that during the late years of the War, a determined effort was made by the Government to locate oilfields in Great Britain, unfortunately without any commercial success. Of the eleven wells put down at the time, only two can be said to have given technically favourable results, one at Hardstoft, in Derbyshire, the other, the Darcy Well, near Edinburgh. Since that time, in the absence of any striking developments, interest in British oil possibilities has naturally waned, and most people are probably unaware that Hardstoft No. 1, first brought in on May 27, 1919, is still contributing its mite to the world's annual production.

Between that date when it was brought in and the end of last year, this well yielded 2500 tons of oil, about 17,500 barrels, equivalent to an average of just under 6 barrels per day. This oil is of good quality, and in many respects resembles some of the best Pennsylvanian crude. The gravity is 0.823 and, according to Hackford's analysis, the oil yields on refinement 7.5 per cent motor spirit, 39 per cent kerosene, 20 per cent gas oil, 30.5 per cent lubricating oils, 0.26 per cent sulphur, and 3 per cent of paraffin wax. In colour it is dark brown, with green fluorescence, has a setting point of $0^{\circ} \mathrm{F}$., and viscosity at $100^{\circ}$ F., Redwood 48 seconds. In common with Pennsylvanian crude, the Hardstoft oil possesses in its lubricating fractions a high percentage of oils suited to steam cylinder lubrication, which makes the analogy between the two crudes a still closer one.

The well is situated on a subsidiary anticline of the Pennine system, actually on a local dome developed on this fold, striking north-west-south-east; the folding is accompanied by much faulting. The well is drilled 3070 feet in a sandy limestone near the top of the main carboniferous limestone, though there seems to be some difference of opinion as to the precise horizon responsible for production.

Interest in Hardstoft has been reawakened by Dr. A. Wade's recent paper on this and two subsequent oilwells at Hardstoft, read before the Institution of
Petroleum Technologists on April 3. The wells are on the Duke of Devonshire's property, and his agent, Capt. J. D. Penrose, has been instrumental in preserving detailed records and history of operations, without which many of the facts would have been lost to the public.

Hardstoft No. 2 was started on May 16, 1924; its location was chosen about 600 feet west of No. 1 , and it was drilled 3125 feet without any other success than a good oil show at 760 feet (a 10-gallon sample after the well had stood for 24 hours), and 20,000 cubic feet of gas at $370 \mathrm{lb}$. pressure from 1620 feet, afterwards utilised as fuel for the boilers. This well went ultimately to water, and with 2800 feet constant head in the hole, which could not be reduced by bailing, it was abandoned on Mar. 24, 1925.

Hardstoft No. 3 was selected 600 feet north of east of No. 1 well and was started on Aug. 5, 1925. In results it was as disappointing as No. 2, though it was carried much deeper (to 3825 feet), being finally abandoned in a bed of lava on June 8,1926 . In this hole, shows of oil were struck at 1900 and 1978 feet, and a gas show at 1812 feet.

While it is evident that the general geological structure of the district is comparatively determined, the results of these three borings, with their contrasted logs and behaviour, show clearly that the subsurface structures are far from being understood, largely, no doubt, due to the extensive faulting prevalent. We are not aware of what particular methods were employed for subsurface correlation of the wellsamples, whether, in point of fact, anything more than casual logging by the drillers was carried out. In any case, the very remote possibility of finding a commercial oil-pool in this area, or in any other in the British Isles for that matter, warrants further drilling neither in Derbyshire nor elsewhere, and although these three wells furnish a pretty problem for the oil geologist, they and their predecessors serve as a warning of what awaits further search for petroleum in Britain.

\section{The Iron-Chromium-Carbon System.}

$\mathrm{N}$ important paper on "The Structure of the IronChromium-Carbon System" was presented by Messrs. Westgren, Phragmén, and Negresco at the May meeting of the Iron and Steel Institute (May 3). As a result of the $\mathrm{X}$-ray determination of the lattice dimensions of various iron-chromium alloys, it is shown that there is a progressive change from end to end of the system, confirming the general view that these metals form with each other an unbroken series of solid solutions. Three carbides of chromium have been detected in the chromium-carbon series, one, cubic, with a probable formula $\mathrm{Cr}_{4} \mathrm{C}$, a trigonal one $\mathrm{Cr}_{7} \mathrm{C}_{3}$, and an orthorhombic carbide $\mathrm{Cr}_{3} \mathrm{C}_{2}$. In the ternary system containing iron, cementite, which may contain chromium to the extent of rather more than 15 per cent, is also present.

For each of the chromium carbides substitution of iron for chromium may to some extent take place. In the cubic form the chromium may be replaced by iron up to about 25 per cent: in the trigonal carbide the iron content may rise to 55 per cent, but in the orthorhombic carbide only a few per cent of chromium can be replaced by iron. No definite double carbide, the presence of which would necessitate the presence of both iron and chromium atoms, is found.

In annealed chromium steels containing only one or two per cent of chromium, the only carbide found is cementite, the iron of which is partially replaced by chromium. The difference of distribution of the carbide in such steels appears to be due not to any definite difference of composition, but to something of the nature of segregation. The carbide in stainless steel is the cubic one saturated with iron. In a steel containing about 1 per cent of nickel, 11 per cent of chromium, and 2 per cent of carbon (used for dies), the trigonal carbide occurs, rather more than half of the chromium of which is replaced by iron. Sections through the ternary solid model show that as the chromium content is raised the area of the $\gamma$-iron phase is gradually reduced and finally disappears: the eutectic occurs at a lower carbon content than in iron-carbon alloys, for example, at about $3 \cdot 7$ per cent with 15 per cent of chromium.

The solubility of the carbide in austenite is reduced as the chromium is increased, and the cementite line consists of two distinct portions corresponding to the solubility of different types of carbide. With 3 per cent chromium, for example, the lower portion of the curve represents the solubility of the trigonal carbide, and the higher temperature region the solubility of cementite. With 15 per cent of chromium the lower temperature portion gives the solubility in the $\gamma$-phase of the cubic carbide, and at higher temperatures of the trigonal one.

No. 3056, VoL. 121] 